\title{
Maintenance and Growth Requirements in Male Dorper $x$ Santa Ines Lambs
}

\author{
Marcilio S. Mendes ${ }^{1}$, Jocely G. Souza ${ }^{1}$, Caio Julio L. Herbster ${ }^{1}$, Antonio S. Brito Neto ${ }^{1}$, \\ Luciano P. Silva ${ }^{1}$, João Paulo P. Rodrigues ${ }^{2}$, Marcos I. Marcondes ${ }^{3}$, Ronaldo L. Oliveira ${ }^{4}$, \\ Leilson R. Bezerra ${ }^{5}$ and Elzania S. Pereira ${ }^{1 *}$ \\ ${ }^{1}$ Department of Animal Science, Federal University of Ceara, Fortaleza, Brazil, ${ }^{2}$ Department of Animal Science, Federal \\ University of Southern and Southeastern Para, Xinguara, Brazil, ${ }^{3}$ Department of Animal Science, Washington State \\ University, Pullman, WA, United States, ${ }^{4}$ Department of Animal Science, Federal University of Bahia, Salvador, Brazil, \\ ${ }^{5}$ Department of Animal Science, Federal University of Campina Grande, Patos, Brazil
}

The aim of this study was to estimate the energy and protein requirements for maintenance and growth of lambs. A total of 35 crossbreed Dorper $\times$ Santa Ines lambs [31 $\pm 1.28 \mathrm{~kg}$ of initial body weight (BW) and 4 months old] were distributed in a completely randomized design with three treatments groups (ad libitum, 30 and 60\% of feed restriction). Five lambs were slaughtered at the beginning of the experimental trial as a reference group to estimate the initial empty BW (EBW) and body composition. When the animals of the ad libitum treatment reached a BW average of $47.2 \mathrm{~kg}$, at day 84 of trial, all lambs were slaughtered. The feed restriction promoted reduction in body fat $(P<0.001)$ and energy concentration $(P<0.001)$, while protein showed a quadratic response $(P=0.05)$. The equations obtained for NEg and NPg requirements were 0.2984 $\times \mathrm{EBW}^{0.75} \times \mathrm{EBWG}^{0.8069}$ and $248.617 \times \mathrm{EBW}^{-0.15546}$, respectively. The net energy (NEm) and protein (NPm) for maintenance were $71.00 \mathrm{kcal} / \mathrm{kg}$ EBW $0.75 /$ day and 1.76 g/kg EBW 0.75 /day, respectively. In conclusion, the NEg and NPg requirement for lambs with $30 \mathrm{~kg}$ of BW and $200 \mathrm{~g}$ of average daily gain (ADG) were $0.736 \mathrm{Mcal} /$ day and 24.38 $\mathrm{g} /$ day, respectively. Our findings indicate that the NEm for crossbreed Dorper $\times$ Santa Ines lambs is similar to those recommended by the international committees; however, we support the hypothesis that the requirements for gain are lower.

Keywords: crossbreed sheep, efficiency, energy, protein, warm areas

\section{INTRODUCTION}

International committees (1-3) play an important role in establishing nutritional recommendations for sheep (4), especially for those in temperate regions. In tropical scenarios, the nutritional requirements recommended by international committees may not be adequate to meet the physiological needs at different stages of the animal's life (5). Evolutionary adaptations to the ecological opportunity of selective feeding in smaller animals, rather than by a physiological or metabolic necessity linked to body mass (6), may explain this phenomenon. Considerable efforts have been made to cluster scientific data and develop feeding systems for ruminants in warm regions (7). In Brazil, studies on the feed composition and nutritional requirements of hair sheep $(5,8,9)$ have generated information to establish a committee to meet the real requirements of 
these animals (10). Warm regions are characterized by constantly high temperatures, sometimes associated with high humidity (3), which induces specificities in the characteristics of both feed and animals (8). Local breeds or crossbreed animals are often used in meat production systems in tropical regions $(11,12)$ and may present specific nutritional requirements (9, 13-15). Furthermore, an adequate supply of nutrients is necessary mainly to reduce protein costs and to reduce environmental pollution.

The objective of the present study was to determine the body composition and to estimate the energy and protein requirements for maintenance and growth in intact male Dorper $\times$ Santa Ines lambs using a comparative slaughter trial.

\section{MATERIALS AND METHODS \\ Site and Ethics Statement}

The trial was conducted at the Animal Nutrition Laboratory of the Department of Animal Science of the Federal University of Ceara in Fortaleza, Ceara State, Brazil ( $\left.30^{\circ} 43^{\prime} 02^{\prime \prime} \mathrm{S}, 33^{\circ} 32^{\prime} 35^{\prime \prime} \mathrm{W}\right)$. Throughout the trial period, the mean daily minimum and maximum air temperatures were $24.6^{\circ} \mathrm{C} \pm 0.82$ and $31.2^{\circ} \mathrm{C}$ \pm 1.32 , respectively, and the minimum and maximum relative humidity were $71.1 \% \pm 7.58$ and $89.1 \% \pm 4.27$, respectively. All procedures involving animal care and use were followed according to the standards established by the Ethics Committee on Animal Research of the Federal University of Ceara, Fortaleza, Brazil (UFC) (Protocol No. 3381260719).

\section{Experimental Design, Animal Management, and Diets}

Thirty-five Dorper $\times$ Santa Ines intact male lambs, with average body weight $(\mathrm{BW})$ of $31 \pm 1.28 \mathrm{~kg}$ and 4 months old were distributed in a completely randomized design with three treatments groups (ad libitum, 30 and $60 \%$ of feed restriction). The diets were formulated with $14 \%$ crude protein (CP) to meet the requirements for a gain of $200 \mathrm{~g} /$ day (1). The total mixed ration (TMR) was composed of Tifton 85 hay, ground corn, soybean meal, dicalcium phosphate, and mineral premix (Table 1). The roughage:concentrate ratio was 60:40. The animals were identified, dewormed, and housed in individual pens $(1.5 \times$ $1.5 \mathrm{~m}$ ) equipped with feed and water troughs. At the beginning of the trial, five lambs were randomly selected and slaughtered to serve as a reference group and used to estimate the initial empty BW (EBW) and body composition. The remaining animals were individually fed (diets as TMR) twice a day (at 0800 and $1600 \mathrm{~h}$ ). The proportional supply of feed for animals in 30 and $60 \%$ feed restriction levels was calculated daily in relation to the average intake of animals subjected to ad libitum intake. Water was provided ad libitum for all animals. The lambs were weighed weekly to calculate the average daily gain (ADG). The trial lasted for 84 days.

\section{Calculations of Metabolizable Energy and Protein Intake}

To evaluate the apparent total-tract digestibility of the dietary constituents and consequently the metabolizable energy intake (MEI), we performed a digestibility trial every 15 days during
TABLE 1 | Ingredient proportions and chemical composition of total mix ration (TMR).

\begin{tabular}{|c|c|c|c|c|}
\hline Ingredient & \multicolumn{4}{|c|}{ g/kg dry matter (DM) } \\
\hline Tifton 85 grass hay & \multicolumn{4}{|c|}{600.0} \\
\hline Ground corn & \multicolumn{4}{|c|}{260.7} \\
\hline Soybean meal & \multicolumn{4}{|c|}{124.0} \\
\hline Dicalcium phosphate & \multicolumn{4}{|c|}{10.2} \\
\hline Mineral premix ${ }^{a}$ & \multicolumn{4}{|c|}{5.1} \\
\hline Nutrient (g/kg DM) & TMR & $\begin{array}{c}\text { Tifton } 85 \\
\text { grass hay }\end{array}$ & $\begin{array}{l}\text { Ground } \\
\text { corn }\end{array}$ & $\begin{array}{c}\text { Soybean } \\
\text { meal }\end{array}$ \\
\hline Dry matter & 911.0 & 916.4 & 906.6 & 900.2 \\
\hline Crude protein & 141.5 & 86.1 & 70.2 & 508.4 \\
\hline Ether extract & 30.0 & 26.7 & 44.3 & 13.6 \\
\hline Ash & 65.5 & 70.2 & 16.3 & 64.4 \\
\hline Neutral detergent fiber & 498.2 & 737.3 & 145.7 & 128.5 \\
\hline NDFap ${ }^{b}$ & 455.2 & 676.0 & 125.9 & 109.4 \\
\hline Acid detergent fiber & 211.9 & 327.0 & 28.2 & 80.6 \\
\hline Total carbohydrate & 763.0 & 817.0 & 869.2 & 413.6 \\
\hline Non-fibrous carbohydrate & 307.8 & 141.0 & 743.4 & 304.2 \\
\hline Total digestible nutrients & 624.5 & - & - & - \\
\hline
\end{tabular}

a Mineral premix was provided per kilogram of total diet DM, and the composition was as follow: $300-200 \mathrm{~g}$ of $\mathrm{Ca}, 50 \mathrm{~g}$ of P, $18 \mathrm{~g}$ of S, $40 \mathrm{~g}$ of $\mathrm{Na}, 16.5 \mathrm{~g}$ of $\mathrm{Mg}, 60 \mathrm{mg}$ of $\mathrm{Co}$, $85 \mathrm{mg}$ of I, 2,000 mg of Mn, $11 \mathrm{mg}$ of Se, 2,100 mg of Zn, 3,960 mg of Fe, $122 \mathrm{mg}$ of $\mathrm{Cu}$, $1,000 \mathrm{mg}$ of $\mathrm{Fl}, 33.6 \mathrm{mg}$ of vitamin $A, 0.55 \mathrm{mg}$ of vitamin $D, 557.1 \mathrm{mg}$ of vitamin $E$. ${ }^{b}$ NDFap, neutral detergent fiber corrected for ash and protein.

the experimental period by collecting feces for three consecutive days at specific times (9). The total digestible nutrient (TDN) was calculated according to Weiss (16). The MEI was estimated from TDN, where digestible energy (DE) was estimated as 4.409 $\mathrm{Mcal} / \mathrm{kg}$ of TDN and converted to metabolizable energy (ME) using an efficiency of $82 \%$, i.e., $\mathrm{ME}=0.82 \times \mathrm{DE}(17)$.

Spot urine samples were collected every 15 days, approximately $4 \mathrm{~h}$ after the morning feeding, during spontaneous urination, used for analysis of purine derivatives to estimate microbial crude protein (MCP). The urine was homogenized, and a $5-\mathrm{ml}$ sample was diluted in $45 \mathrm{ml} 0.036 \mathrm{~N}$ sulfuric acid (1:10 ratio). The absorbed microbial purines and intestinal flow of microbial nitrogen were estimated from the equations proposed by Chen and Gomes (18). The MCP was calculated by multiplying the TDN intake (TDNI, kg/day) by the average of microbial efficiency of $135.5 \mathrm{~g} \mathrm{MCP} / \mathrm{kg}$ TDNI. The rumen degradable protein (RDP) was considered equal to MCP. The truly digestible microbial crude protein (tdMCP) was estimated by the followed equation:

$$
\operatorname{tdMCP}=(135.5 \times \mathrm{TDNI}) \times 0.64
$$

where $\mathrm{TDNI}=\mathrm{TDN}$ intake, and 0.64 is the value considering that the MCP is constituted of $80 \%$ of amino acids with intestinal digestibility of $80 \%(17)$.

The rumen undegradable protein (RUP) intake was calculated as $\mathrm{CP}$ intake minus $\mathrm{RDP}$. The digestible rumen 
undegradable protein (dRUP) was calculated according to the followed equation:

$$
\mathrm{dRUP}=\mathrm{RUP} \times 0.80
$$

where 0.80 is the fixed value of $80 \%$ in digestibility of RUP in the small intestine (17). The metabolizable protein intake (MPI) was calculated as the sum of the tdMCP and dRUP.

\section{Slaughter, Sampling, and Chemical Analyses}

When the ad libitum group reached a BW average of $47.2 \mathrm{~kg}$, all animals were slaughtered. Before slaughter, fasted BW (FBW) was determined as the BW after $18 \mathrm{~h}$ of no access to feed and water. At slaughter, lambs were stunned with a captive pistol, followed by severing of the jugular vein and carotid artery. Blood collection procedures, gastrointestinal tract, organs, and other parts of the body were performed followed as described by Pereira et al. (8). The EBW was calculated by subtracting the weight of gastrointestinal and bladder contents from FBW. The carcasses were refrigerated at $4^{\circ} \mathrm{C}$ for $24 \mathrm{~h}$ and then were divided into right and left half-carcasses. Subsequently, the right half-carcasses, non-carcass components (blood, head, hooves, internal organs, and the cleaned gastrointestinal tract), and hides were frozen and then cut with a band saw and ground in an industrial cutter. After grinding and homogenization, samples of $500 \mathrm{~g}$ were taken and then frozen at $-20^{\circ} \mathrm{C}$. The samples were placed in a forced-ventilation oven at $55^{\circ} \mathrm{C}$ for $72 \mathrm{~h}$, after which they were defatted by extraction with ether in a Soxhlet apparatus for $12 \mathrm{~h}$, method number 920.39 (19). Afterwards, they were ground in a ball mill for the subsequent chemical analyses of body composition. The dry matter (DM), ash, and CP content levels were determined by fat-free samples, following the methods described below for experimental ingredients diets. The body water content was calculated as $100 \%$ minus DM.

For analysis, feed, orts, and fecal samples were dried in a forced-air oven at $55^{\circ} \mathrm{C}$ for $72 \mathrm{~h}$ and then ground in a Wiley mill (TE-650; Tecnal, Piracicaba, São Paulo, Brazil) with a 1$\mathrm{mm}$ sieve. The DM (method 967.03), CP (method 981.10), ash (method 942.05), ether extract (EE, method 920.39), and acid detergent fiber (ADF, method 913.18) were conducted as described by the Association of Official Analytical Chemists (19). The neutral detergent fiber (NDF) content was performed as described by Van Soest et al. (20) using thermostable alphaamylase without sodium sulfite and corrected for residual ash (21) and residual nitrogenous compounds (22). The total carbohydrate content was calculated according to (23), and nonfibrous carbohydrates were calculated using an equation adapted from Weiss (16).

\section{Models and Calculations}

To estimate EBW (kg) and EBW gain (EBWG, kg/day), equations obtained from the linear regression of the FBW against the BW, EBW against the FBW and EBWG against the ADG were generated. Only performance animals were used to develop the EBWG equation.
The empty body weight energy (BEC) content was obtained from the body contents of protein (EBP) and fat (EBF) and their respective caloric equivalents of 5.6405 and $9.3929 \mathrm{Mcal} / \mathrm{kg}$ (24).

The retained energy ( $\mathrm{RE}$ ) was obtained as the difference between final and initial body energy contents. The initial body energy contents were estimated from the reference group data by regressing body energy content on EBW.

The net energy requirement for weight gain (NEg, Mcal/day) was estimated using the model used by Chizzotti et al. (25):

$$
\mathrm{NEg}=\beta_{0} \times \mathrm{EBW}^{0.75} \times \mathrm{EBWG}^{\beta_{1}}
$$

where $\beta_{0}$ and $\beta_{1}=$ coefficients obtained from the regression of the logarithm of RE (Mcal/kg EBW ${ }^{0.75} /$ day) against the logarithm of EBWG (kg/day).

Heat production (HP) was calculated as the difference between MEI and RE. The net energy requirement for maintenance $(\mathrm{NEm})$ was assumed to be the intercept $\left(\beta_{0}\right)$ of the exponential regression between $\mathrm{HP}$ and MEI as proposed by Ferrell and Jenkins (26):

$$
\mathrm{HP}=\beta_{0} \times \mathrm{e}^{\left(\beta_{1} \times \mathrm{MEI}\right)}
$$

where HP and MEI are expressed in Mcal/kg EBW $\mathrm{EB}^{0.75} /$ day, and $\beta_{1}$ is the equation parameter.

The metabolizable energy requirements for maintenance (MEm), expressed as Mcal/kg EBW $\mathrm{EB}^{0.75} /$ day, were estimated by the iterative method as the point where MEI is equal to HP (i.e., the point at which there is no energy retention in the body). In addition, the efficiency of use of metabolizable energy for maintenance $\left(\mathrm{k}_{\mathrm{m}}\right)$ was estimated by the ratio between NEm and MEm.

The efficiency of metabolizable energy use for gain $\left(\mathrm{k}_{\mathrm{g}}\right)$ was considered the slope $\left(\beta_{1}\right)$ of the regression of the RE against MEI:

$$
\mathrm{RE}=\beta_{0}+\beta_{1} \times \mathrm{MEI}
$$

where $\mathrm{RE}=$ retained energy $\left(\mathrm{Mcal} / \mathrm{kg} \mathrm{EBW} \mathrm{E}^{0.75} / \mathrm{day}\right), \mathrm{MEI}=$ metabolizable energy intake (Mcal $/ \mathrm{kg} \mathrm{EBW} \mathrm{E}^{0.75} /$ day), and $\beta_{0}=$ the equation parameter.

To calculate the net protein requirements for any body weight gain (NPg, g/day), we adjusted the following model:

$$
\mathrm{NPg}=\beta_{1} \times 10^{\beta_{0}} \times \mathrm{EBW}^{\left(\beta_{1}-1\right)}
$$

where $\beta_{0}$ and $\beta_{1}=$ regression parameters. Reference and performance animals were included in this model.

To estimate the net protein requirements for maintenance (NPm, g/kg EBW $\mathrm{E}^{0.75} /$ day), the retained protein was plotted as a function of MPI according following equation:

$$
\mathrm{RP}=\beta_{0}+\beta_{1} \times \mathrm{MPI}
$$

where $\mathrm{RP}=$ retained protein $\left(\mathrm{g} / \mathrm{kg} \mathrm{EBW}^{0.75} / \mathrm{day}\right), \mathrm{MPI}=$ metabolizable protein intake (g/kg EBW ${ }^{0.75} /$ day), $\beta_{0}=\mathrm{NPm}$, and $\beta_{1}=\mathrm{k}_{\mathrm{pg}}$.

The metabolizable protein requirement for maintenance $(\mathrm{MPm})$ was obtained from the adaptation of the Wilkerson 
et al. (27) and National Research Council (NRC) (17) equations. MPI was related to the EBWG of the lambs according to the following equation:

$$
\mathrm{MPI}=\beta_{0}+\beta_{1} \times \mathrm{EBWG}
$$

where MPI = MP intake (g/day), EBWG = EBW gain $(\mathrm{kg} /$ day $)$, and $\beta_{0}$ and $\beta_{1}=$ parameters determined from a linear regression. Posteriorly, the ratio between the intercept $\left(\beta_{0}\right)$ and the average $\mathrm{EBW}^{0.75}$ of the lambs was considered as MPm:

$$
\mathrm{MPm}=\frac{\beta_{0}}{\mathrm{EBW}^{0.75}}
$$

The efficiency of metabolizable protein use for maintenance $\left(\mathrm{k}_{\mathrm{pm}}\right)$ was calculated as NPm/MPm.

The estimated requirements based on the EBW were converted to the FBW using the factor (1.14), which was obtained from the ratio $\mathrm{FBW}^{0.75} / \mathrm{EBW}^{0.75}$.

\section{Statistical Analysis}

A linear model analysis was performed following a completely randomized design. The statistical model is Yij $=\mu+\alpha \mathrm{i}+$ eij, where Yij $=$ value observed that received treatment $\mathrm{i}, \mu=$ overall mean, $\alpha \mathrm{i}=$ fixed effect of treatment $\mathrm{i}$; eij $=$ random error $\sim \operatorname{NID}(0, \sigma 2)$.

Treatments were analyzed as orthogonal partition into linear and quadratic effects. A significance level of $5 \%(\alpha=0.05)$ was adopted in this study. We carried out all analysis at SAS System Software (SAS 9.0, SAS Institute Inc., Cary, NC, USA; 2003), ANOVA with generalized linear model (GLM) procedure, linear regressions with REG procedure, and nonlinear models using NLIN procedure along with Marquardt iterative method.

\section{RESULTS}

\section{Performance, Intake, Energy Retention, and Body Composition}

The final BW, ADG, EBW, and EBWG showed a linear response by feed restriction $(P<0.001)$. The generated equations to predict EBW and EBWG for all experimental animals were FBW $(\mathrm{kg})=0.756( \pm 0.659)+0.912( \pm 0.017) \times \mathrm{BW}\left[\mathrm{R}^{2}=0.99 ;\right.$ root mean square error $(\mathrm{RMSE})=0.673]$; EBW $(\mathrm{kg})=0.547( \pm 0.564)$ $+0.827( \pm 0.016) \times \mathrm{FBW}\left(\mathrm{R}^{2}=0.99 ; \mathrm{RMSE}=0.631\right) ; \mathrm{EBWG}$ $(\mathrm{kg} /$ day $)=0.043( \pm 0.011)+0.590( \pm 0.054) \times$ ADG $\left(\mathrm{R}^{2}=0.94\right.$; $\mathrm{RMSE}=0.006)$.

The DMI (kg/day; g/kg EBW $0.75 /$ day), MEI, RE, HP (Mcal/kg $\mathrm{EBW}^{0.75} /$ day), fat (\%EBW), and energy (\%EBW) decreased linearly with increased feed restriction $(P<0.001)$; however, the protein (\%EBW) showed a quadratic response by feed restriction $(P=0.05)$ (Table 2).

The BFC and BEC increased with increasing BW; however, BPC decreased with increasing BW (Table 3).

\begin{tabular}{|c|c|c|c|c|c|c|c|c|}
\hline \multirow[t]{2}{*}{ Parameters } & \multirow[t]{2}{*}{ REF } & \multirow[t]{2}{*}{ SEM } & \multicolumn{3}{|c|}{ Treatments groups } & \multirow[t]{2}{*}{ SEM } & \multicolumn{2}{|c|}{$P$-value } \\
\hline & & & $\mathrm{AL}$ & $30 \%$ & $60 \%$ & & Linear & Quadratic \\
\hline Initial BW (kg) & 31.2 & 2.70 & 31.0 & 31.8 & 31.9 & 0.400 & 0.124 & 0.532 \\
\hline Final BW (kg) & - & - & 47.2 & 40.5 & 29.3 & 0.733 & $<0.001$ & 0.020 \\
\hline FBW (kg) & 29.2 & 1.95 & 40.9 & 36.0 & 27.0 & 0.604 & $<0.001$ & 0.010 \\
\hline ADG (g/day) & - & - & 192.2 & 103.7 & -31.0 & 10.578 & $<0.001$ & 0.086 \\
\hline EBW (kg) & 24.3 & 1.33 & 30.6 & 28.1 & 24.0 & 0.288 & $<0.001$ & 0.040 \\
\hline EBWG (g/day) & - & - & 152.5 & 84.3 & -13.6 & 7.091 & $<0.001$ & 0.100 \\
\hline \multicolumn{9}{|l|}{ Intake and energy balance } \\
\hline DMI (kg/day) & - & - & 1.369 & 0.972 & 0.513 & 0.033 & $<0.001$ & 0.454 \\
\hline DMI (g/kg EBW $0.75 / d a y)$ & - & - & 104.9 & 79.6 & 47.2 & 1.998 & $<0.001$ & 0.160 \\
\hline CPI (g/kg EBW $0.75 /$ day) & - & - & 15.3 & 11.1 & 6.6 & 0.283 & $<0.001$ & 0.734 \\
\hline MEl (Mcal/kg EBW0.75/day) & - & - & 0.231 & 0.180 & 0.110 & 0.005 & $<0.001$ & 0.144 \\
\hline RE (Mcal/kg EBW $0.75 /$ day) & - & - & 0.04 & 0.02 & 0.00 & 0.003 & $<0.001$ & 0.262 \\
\hline HP (Mcal/kg EBW $0.75 /$ day) & - & - & 0.189 & 0.155 & 0.111 & 0.005 & $<0.001$ & 0.363 \\
\hline \multicolumn{9}{|l|}{ Body composition } \\
\hline Water (\%EBW) & 65.65 & 2.31 & 60.40 & 61.06 & 62.36 & 0.735 & 0.071 & 0.720 \\
\hline Protein (\%EBW) & 18.46 & 0.74 & 16.53 & 17.99 & 17.42 & 0.405 & 0.131 & 0.050 \\
\hline Fat (\%EBW) & 12.26 & 2.63 & 19.09 & 16.46 & 14.62 & 0.840 & $<0.001$ & 0.705 \\
\hline Ash (\%EBW) & 3.57 & 0.36 & 3.63 & 3.99 & 4.21 & 0.126 & 0.003 & 0.670 \\
\hline Energy (Mcal/kg EBW) & 2.19 & 0.25 & 2.72 & 2.56 & 2.36 & 0.069 & $<0.001$ & 0.811 \\
\hline
\end{tabular}

TABLE 2 | Effects of feed restriction on performance, intake and energy retention, and body composition in intact males Dorper $\times$ Santa Ines lambs.

REF, reference group; $A L$, ad libitum intake; $30 \%$ and 60\%, feed restriction; BW, body weight; FBW, fasted body weight; ADG, average daily gain; EBW, empty body weight; EBWG, empty body weight gain; DMI, dry matter intake; CPI, crude protein intake; MEl, metabolizable energy intake; RE, retained energy; HP, heat production; SEM, standard error of the mean. $P$-value for treatment effect without the reference group. 
TABLE 3 | Body fat, protein, and energy contents of intact male Dorper $\times$ Santa Ines lambs from 30 to $50 \mathrm{~kg}$ BW.

\begin{tabular}{lcccc}
\hline $\begin{array}{c}\text { BW } \\
\mathbf{( k g )}\end{array}$ & $\begin{array}{c}\text { EBW } \\
\mathbf{( k g )}\end{array}$ & $\begin{array}{c}\text { BFC } \\
\mathbf{( g / k g ~ E B W )}\end{array}$ & $\begin{array}{c}\text { BPC } \\
\mathbf{( g / k g ~ E B W ) ~}\end{array}$ & $\begin{array}{c}\text { BEC } \\
\text { (Mcal/kg EBW) }\end{array}$ \\
\hline 30 & 28.17 & 134.23 & 179.81 & 2.30 \\
35 & 27.61 & 150.20 & 175.75 & 2.43 \\
40 & 31.39 & 165.65 & 172.28 & 2.55 \\
45 & 35.17 & 180.70 & 169.26 & 2.66 \\
50 & 38.94 & 195.32 & 166.60 & 2.77 \\
\hline
\end{tabular}

BW, body weight; EBW, empty body weight; BFC, body fat content; BPC, body protein content; BEC, body energy content.

TABLE 4 | Net energy and protein requirements for weight gain in intact male Dorper $\times$ Santa Ines lambs from 30 to $50 \mathrm{~kg} \mathrm{BW}$.

\begin{tabular}{|c|c|c|c|c|c|}
\hline \multirow[t]{2}{*}{ BW (kg) } & \multirow[t]{2}{*}{ EBW (kg) } & \multicolumn{4}{|c|}{ ADG (g/day) } \\
\hline & & 100 & 150 & 200 & 250 \\
\hline \multicolumn{6}{|c|}{ Energy (Mcal/day) } \\
\hline 30 & 28.17 & 0.508 & 0.624 & 0.736 & 0.843 \\
\hline 35 & 27.61 & 0.567 & 0.697 & 0.821 & 0.941 \\
\hline 40 & 31.39 & 0.625 & 0.768 & 0.904 & 1.036 \\
\hline 45 & 35.17 & 0.680 & 0.836 & 0.985 & 1.128 \\
\hline 50 & 38.94 & 0.734 & 0.902 & 1.063 & 1.218 \\
\hline \multicolumn{6}{|c|}{ Protein (g/day) } \\
\hline 30 & 28.17 & 15.14 & 19.89 & 24.38 & 28.86 \\
\hline 35 & 27.61 & 15.06 & 19.44 & 23.82 & 28.21 \\
\hline 40 & 31.39 & 14.77 & 19.06 & 23.35 & 27.65 \\
\hline 45 & 35.17 & 14.51 & 18.73 & 22.95 & 27.16 \\
\hline 50 & 38.94 & 14.28 & 18.43 & 22.58 & 26.74 \\
\hline
\end{tabular}

BW, body weight; EBW, empty body weight; $A D G$, average daily gain.

\section{Energy and Protein Requirements}

The equation generated to estimate the $\mathrm{NEg}$ (Mcal $/ \mathrm{kg}$ $\mathrm{EBW}^{0.75}$ /day) was $0.2984 \times \mathrm{EBW}^{0.75} \times \mathrm{EBWG}^{0.8069}$. The $\mathrm{NEg}$ estimated for intact male Dorper $\times$ Santa Ines lambs were $0.736 \mathrm{Mcal} /$ day, considering a BW of $30 \mathrm{~kg}$ and ADG of $200 \mathrm{~g} /$ day (Table 4). The $\mathrm{kg}_{\mathrm{g}}$ obtained was 0.348 . The value of HP when MEI is zero (NEm) was estimated to be $0.071 \mathrm{Mcal} / \mathrm{kg} \mathrm{EBW}{ }^{0.75} /$ day (Figure 1). The MEm was $0.115 \mathrm{Mcal} / \mathrm{kg} \mathrm{EBW}^{0.75} / \mathrm{day}$, and the $\mathrm{k}_{\mathrm{m}}$ was 0.61 .

The equation to estimate the NPg (g/day) was NPg $=248.617$ $\times \mathrm{EBW}^{-0.15546}$. The NPg was $24.38 \mathrm{~g} /$ day, considering a $\mathrm{BW}$ of $30 \mathrm{~kg}$ and an ADG of $200 \mathrm{~g} /$ day (Table 4). The relationship between the MPI and the EBWG is show in Figure 2. The $\mathrm{MPm}$ was $4.31 \mathrm{~g} / \mathrm{kg} \mathrm{EBW}^{0.75} /$ day. The $\mathrm{NPm}$ was $1.76 \mathrm{~g} / \mathrm{kg}$ $\mathrm{EBW}^{0.75} /$ day, and the $\mathrm{k}_{\mathrm{pg}}$ was 0.347 (Figure 2).

\section{DISCUSSION}

Brazilian studies with hair sheep have generated a considerable amount of data that has contributed to improving our understanding of nutritional requirements. Nutrient

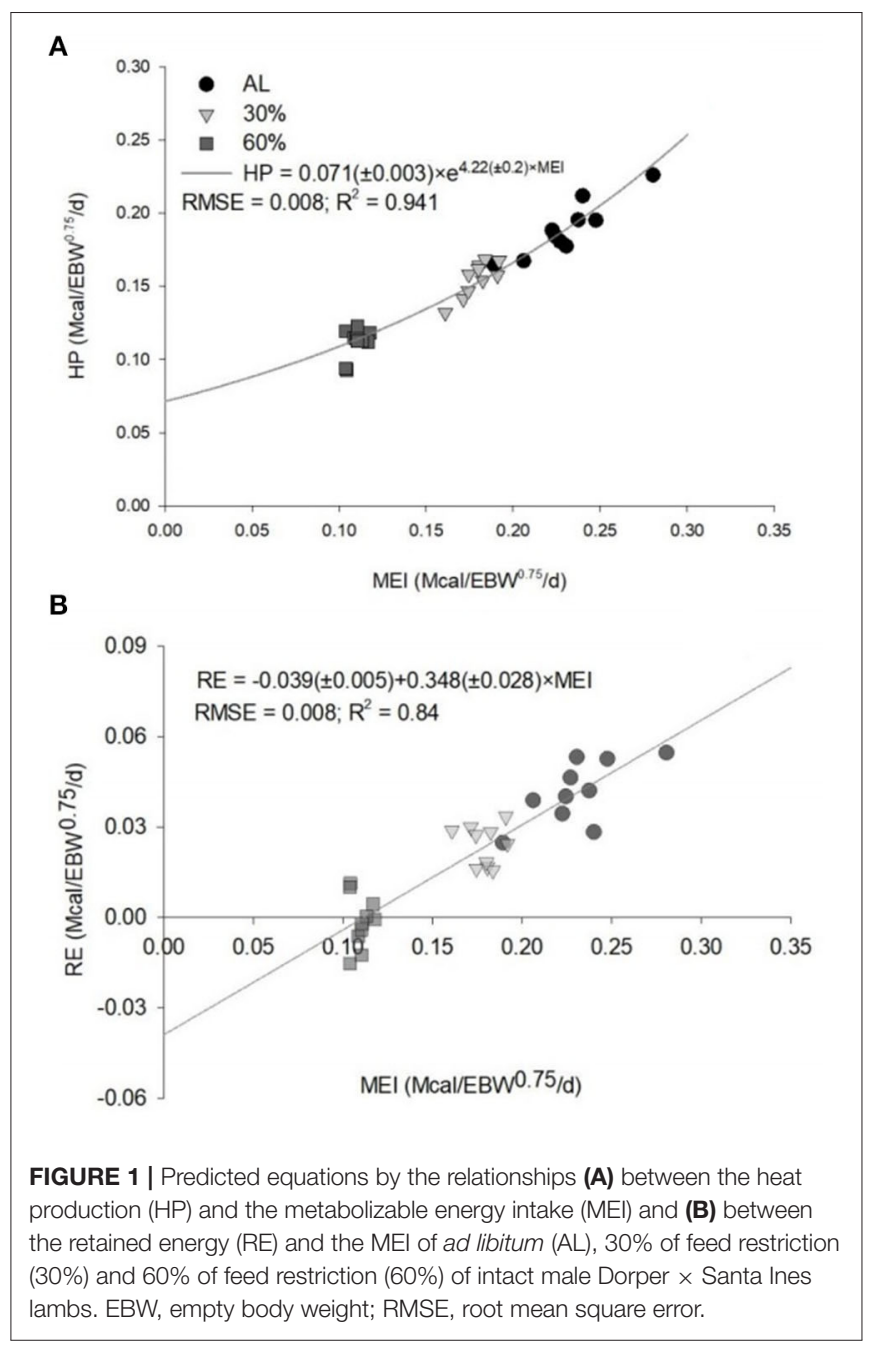

requirements are not static (4) and vary with genetic selection (11) and crossbreeding (28). Factors such as mathematical models (29), environmental conditions (5), genotype (30) body composition, and feed quality (9) may influence the NEm requirements.

The body composition and body part masses were predicted for a wide range of live weights, that is, from 30 to $50 \mathrm{~kg}$ of Dorper $\times$ Santa Ines. In the absence of specific estimates in the literature, the results of this study might be useful for predicting the protein and energy requirements for this category. The $\mathrm{NEm}$ obtained in our study was $0.071 \mathrm{Mcal} / \mathrm{kg} \mathrm{EBW}^{0.75} /$ day (or $0.062 \mathrm{Mcal} / \mathrm{kg} \mathrm{FBW}{ }^{0.75} /$ day). This value is $16.9 \%$ greater $(0.059$ $\left.\mathrm{Mcal} / \mathrm{kg} \mathrm{EBW} \mathrm{E}^{0.75} / \mathrm{day}\right)$ in relation to the value obtained with hair sheep by Oliveira et al. (5). The value determined in this study was consistent with the unadjusted energy requirement value of the NRC (1), which is $0.062 \mathrm{Mcal} / \mathrm{kg} \mathrm{FBW}^{0.75} /$ day. The crossbreed Dorper $\times$ Santa Ines lamb has early maturing when compared to Santa Ines $(8,13)$ and Morada Nova (9) breeds. The Dorper genotype presents a fast development (11), and it may influence the NEm result. We also verified that MEm was consistent with those reported by NRC (1) (0.102 vs. $0.096 \mathrm{Mcal} / \mathrm{day}$, 


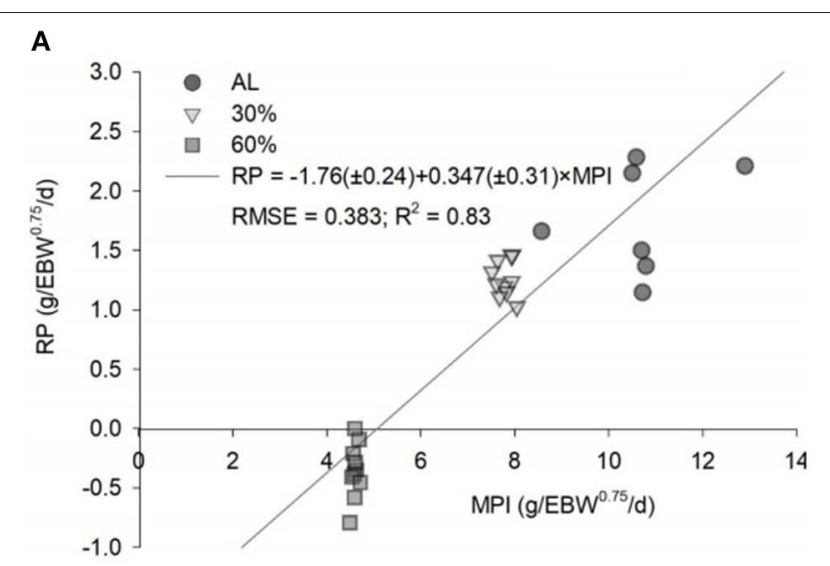

B

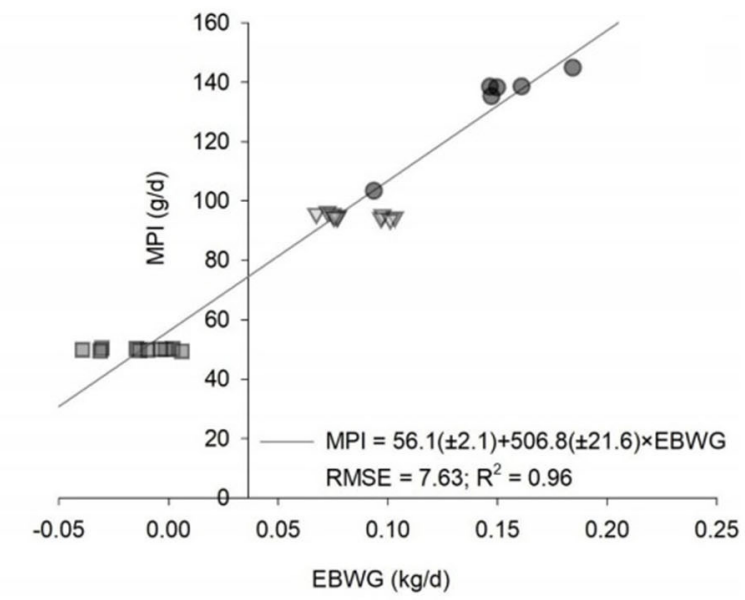

FIGURE 2 | Predicted equations by the relationships (A) between the retained protein (RP) and the metabolizable protein intake (MPI) and (B) between the MPI and the empty BW gain (EBWG) of ad libitum (AL), 30\% of feed restriction $(30 \%)$ and $60 \%$ of feed restriction (60\%) of intact male Dorper $\times$ Santa Ines lambs. EBW, empty body weight; RMSE, root mean square error.

respectively). It is known that, for the same gain, protein and energy cost may be different depending on the body composition (31). Energetically, fat deposition is more efficient than protein deposition due to the different biochemical pathways and the greater daily turnover of protein than fat (32). The efficiency use of $\mathrm{ME}$ for protein deposition $\left(\mathrm{k}_{\mathrm{p}}\right)$ ranges from 10 to $40 \%$, as the efficiency use of ME for fat deposition $\left(\mathrm{k}_{\mathrm{f}}\right)$ ranges from 60 to $80 \%$ (33).

It is reported that $\mathrm{ME}$ requirements of ruminants raised in tropical regions are higher than the published values for temperate genotypes (15). However, the expression of the allometric relationship that smaller species requiring more per unit body weight, while mathematically correct, would only explain anything if it was shown that some other factor relates directly to unit body weight. The statement that smaller animals have higher mass-specific metabolic requirements than large animals express the same fact as the statement that smaller animals have the same metabolic requirements as large animals on a metabolic body weight basis (note that the allometric relationship also allows to correctly state that smaller animals have lower absolute metabolic requirements than large animals).

The NEg requirements obtained in our study were lower than those recommended by the NRC (1) for 4-month-old early maturing lambs. Thus, for a lamb with $30 \mathrm{~kg}$ of BW and ADG of $200 \mathrm{~g} /$ day, the $\mathrm{NEg}$ requirement estimated in the current study was $0.736 \mathrm{Mcal} /$ day, $19 \%$ lower than that estimated by NRC (1) (0.910 Mcal/day). As well as NEg estimates, $\mathrm{k}_{\mathrm{g}}$ values may be affected by the composition of weight gain, so that in sheep, values between 0.18 and 0.30 and 0.66 and 0.74 have been reported for protein deposition and fat, respectively $(14,34)$. In our study, the $k_{\mathrm{g}}$ was 0.348 . The Small Ruminant Nutrition System (SRNS) uses $\mathrm{k}_{\mathrm{g}}$ estimated from the proportion of energy retained in the form of protein, considering 0.27 and 0.68 for protein and fat, respectively (35). Higher values of $\mathrm{k}_{\mathrm{g}}$ of 0.345 and 0.409 for animals fed with medium- and low-quality forage, respectively, were reported for crossbreed animals Dorper $\times$ Santa Ines. These differences being greater associated with changes in the efficiency of fat deposition (14).

In comparative terms, the MPm of $3.78 \mathrm{~g} / \mathrm{kg} \mathrm{BW}^{0.75} /$ day is higher than NRC (1) of $3.27 \mathrm{~g} / \mathrm{kg} \mathrm{BW}^{0.75} /$ day. Our estimates are similar to those reported by Wilkerson et al. (27) for beef cattle (3.8 g/kg BW $\mathrm{BW}^{0.75} /$ day). For all types of growing goats, MPm of $3.07 \mathrm{~g} / \mathrm{kg} \mathrm{BW}^{0.75} /$ day was reported by Luo et al. (36). Higher requirements for $\mathrm{MPm}$ can be attributed to the high rates of metabolism of visceral organs and tissues during the growth of the animal, which increases maintenance costs compared to animals that have reached maturity weight (37). Differences in the MP requirements are attributed to dietary quality. The contribution of MCP to the MP intake in our study was computed as $135.5 \mathrm{~g} \mathrm{MCP} / \mathrm{kg}$ TDN intake. Therefore, the estimate of 3.78 $\mathrm{g} / \mathrm{kg} \mathrm{BW} \mathrm{BW}^{0.75} /$ day is not independent of the estimate of MCP, meaning that $3.78 \mathrm{~g} / \mathrm{kg} \mathrm{BW}^{0.75} /$ day is valid only when the $135.5 \mathrm{~g}$ $\mathrm{MCP} / \mathrm{kg}$ TDN intake is used to predict MCP. Animals fed roughages of low nutritional value tend to have low $\mathrm{N}$ retention and consequently higher protein requirements. In our study, the $\mathrm{k}_{\mathrm{pm}}$ obtained was 0.41 , which is lower than the values adopted by the international committees. However, the great variability that exists between the values adopted [0.75 for Agricultural Research Council (ARC) (24); 0.67 for Commonwealth Scientific and Industrial Research Organization (CSIRO) (37), and NRC (1); 1.0 for Agricultural and Food Research Council (AFRC) $(38,39)$; and 0.70 for CSIRO (2)] illustrates the uncertainty about the actual efficiency of use of the absorbed amino acids (AA). The efficiency of use of the metabolizable protein depends on the source of MP for the synchronization between the AA profile of the metabolized protein and the maintenance-related tissues; therefore, it is positively correlated with the protein biological value (40). In addition, the estimates of MPI can contribute to the variability observed in the efficiency of protein use. An inaccuracy associated with the mathematical models used to estimate the intake of RUP and the constant values used to calculate the digestible fractions of the true microbial protein and RUP (0.80) may contribute to the underestimation or overestimation of MPI. Differences in the need for metabolizable 
proteins can be attributed to the quality of the diet (15). Given the uncertainties in the determination of MCP, current estimates of metabolizable protein required for maintenance are biased. The use of empirical equations to predict MCP, which, in turn, is used to estimate metabolizable protein intake, is risky because it establishes a dependency between these estimates and creates a specificity that is not appropriate for mechanistic systems. Despite the existence of data and knowledge about the partitioning of retained energy into fat and protein, the prediction of retained protein remains unsatisfactory.

In our study, the NPg decreased as the lambs' body weight increased. The reduction in BW protein concentration with advancing maturity has been clearly established in sheep (41) and determines the decrease in daily requirements for weight gain. As the animal grows, total protein and ash content increase at similar rates in early life decelerating later. The NPg requirements are represented by the amount of AA made available to the animal tissue, discounting the AA pool that is metabolically prioritized by the animal to counteract the endogenous $\mathrm{N}$ losses by the animal's organism, such as losses of CP in feces, urine, wool, and/or scurf and fiber (1). The NPg estimates presented in the NRC (1) are higher than the estimates obtained for Dorper $\times$ Santa Ines sheep. The high rate of body fat deposition reported by the NRC (1) differs from our estimates. Many factors can alter the gain composition during the feeding period, but it is assumed that the composition of the fat-free matter remains constant. Similarly, the heats of combustion of fat and protein are assumed to be invariable, although lower differences might exist as a result of differences in the determination. The $\mathrm{k}_{\mathrm{pg}}$ estimated in the current study (0.35) was higher than those obtained in hair sheep trials $(8,9)$. As with the efficient use of metabolizable protein for maintenance, there is no consensus regarding the values of $\mathrm{k}_{\mathrm{pg}}$, which have varied between 0.59 (39) and $0.70(1,2,37)$, the $\mathrm{k}_{\text {pg }}$ obtained with Dorper $\times$ Santa Ines sheep is compatible with the idea that the efficiency of use of the metabolizable protein is influenced by the energy supply to the animals, which, possibly, is associated with the reduction in the use of AA for hepatic gluconeogenesis where energy intake is high.

The use of recommendations based on international feeding systems has as consequence nutrient wastage for Dorper $\times$ Santa Ines between 30 and $50 \mathrm{~kg}$ of body weight, since the amounts of energy and protein required for the gain of the sheep were lower than the values recommended by international

\section{REFERENCES}

1. NRC. Nutrient Requirements of Small Ruminants: Sheep, Goats, Cervids and New World Camelids. Washington, DC: National Academy Press (2007).

2. CSIRO. Nutrient Requirements of Domesticated Ruminants. Collingwood: CSIRO Publishing (2007).

3. INRA. INRA Feeding System for Ruminants. Wageningen: Wageningen Academic Publishers (2018).

4. Cannas A, Tedeschi LO, Fox DG, Pell AN, Van Soest PJ. A mechanistic model for predicting the nutrient requirements and feed biological values for sheep. J Anim Sci. (2004) 82:149-69. doi: 10.2527/2004.821149x

5. Oliveira AP, Pereira ES, Biffani S, Medeiros AN, Silva AMA, Oliveira RL, et al. Meta-analysis of the energy and protein requirements of hair sheep raised committees. These findings are of great importance for the targeted improvement of nutrient levels in ruminants. In conclusion, the net and metabolizable energy requirements for maintenance of crossbreed Dorper $\times$ Santa Ines lambs were 71.00 and $115.00 \mathrm{kcal} / \mathrm{kg} \mathrm{EBW}^{0.75} /$ day, respectively. The net energy and protein requirements for gain could be obtained by the respective equations NEg $(\mathrm{Mcal} /$ day $)=0.2984 \times \mathrm{EBW}^{0.75} \times \mathrm{EBWG}^{0.8069}$ and $\mathrm{NPg}(\mathrm{g} /$ day $)=248.617 \times \mathrm{EBW}^{-0.15546}$.

\section{DATA AVAILABILITY STATEMENT}

The raw data supporting the conclusions of this article will be made available by the authors, without undue reservation.

\section{ETHICS STATEMENT}

The animal study was reviewed and approved by Ethics Committee on Animal Research of the Federal University of Ceara, Fortaleza, Brazil (UFC) (Protocol number 3381260719).

\section{AUTHOR CONTRIBUTIONS}

ESP is the leader of the research project and responsible for all parts of the study, from the project to the publication. MSM, CJLH, and ASBN contributed to performing the experiment and collecting the data. ESP, JGS, JPPR, RLO, and LRB contributed to the writing, review, and editing of the manuscript. JPPR, MIM, and LPS analyzed the data. All authors contributed to the article and approved the submitted version.

\section{FUNDING}

This research was supported by the Institutos Nacionais de Ciência e Tecnologia (INCT), Conselho Nacional de Desenvolvimento Científico e Tecnológico (CNPq-Brasil, process number 425358/2018-6), and the Coordenação de Aperfeiçoamento de Pessoal de Nível Superior (CAPES).

\section{ACKNOWLEDGMENTS}

The authors would like to acknowledge the financial assistance of the INCT, CNPq-Brazil, and CAPES. in the tropical region of Brazil. J Anim Physiol Anim Nutr. (2017) 102:E5260. doi: $10.1111 /$ jpn. 12700

6. Clauss M, Steuer P, Müller DW, Codron D, Hummel J. Herbivory and body size: allometries of diet quality and gastrointestinal physiology, and implications for herbivore ecology and dinosaur gigantism. PLOS ONE. (2013) 8:E68714. doi: 10.1371/journal.pone.0068714

7. BR-CORTE. Nutrient Requirements of Zebu and Crossbred Cattle. $\quad 3 r d . E d n$. Viçosa: Suprema Gráfica Ltda (2016). doi: 10.5935/978-85-8179-111-1.2016B002

8. Pereira ES, Lima FWR, Marcondes MI, Rodrigues JPP, Campos ACN, Silva LP et al. Energy and protein requirements of Santa Ines lambs, a breed of hair sheep. Animal. (2017) 11:2165-74. doi: 10.1017/S175173111 7001185 
9. Pereira ES, Pereira MWF, Marcondes MI, Medeiros NA, Oliveira RL, Silva LP, et al. Maintenance and growth requirements in male and female hair lambs. Small Rumin Res. (2018) 159:75-83. doi: 10.1016/j.smallrumres.2017.11.003

10. Herbster CJL, Silva LP, Marcondes MI, Garcia IFF, Oliveira R, Cabral L, et al. Weight adjustment equation for hair sheep raised in warm conditions. Animal. (2020) 14:1718-23. doi: 10.1017/S1751731120000294

11. Malhado CHM, Carneiro PLS, Affonso PRAM, Souza AAO, Sarmento JLR. Growth curves in Dorper sheep crossed with the local Brazilian breeds, Morada Nova, Rabo Largo, and Santa Inês. Small Rumin Res. (2009) 84:1621. doi: 10.1016/j.smallrumres.2009.04.006

12. Souza DA, Villarroel ABS, Pereira ES, Osório JCS, Teixeira A. Growth performance, feed efficiency and carcass characteristics of lambs produced from Dorper sheep crossed with Santa Inês or Brazilian Somali sheep. Small Rumin Res. (2013) 114:51-5. doi: 10.1016/j.smallrumres.2013.06.006

13. Regadas Filho JGL, Pereira ES, Pimentel PG, Villarroel ABS, Medeiros AN, Fontenele RM. Body composition and net energy requirements for Santa Ines lambs. Small Rumin Res. (2013) 109:10712. doi: 10.1016/j.smallrumres.2012.07.011

14. Galvani DB, Pires AV, Susin I, Gouvêa VN, Berndt A, Chagas LJ, et al. Energy efficiency of growing ram lambs fed concentrate-based diets with different roughage sources. J Anim Sci. (2014) 92:250-63. doi: 10.2527/jas.2012-6017

15. Salah N, Sauvant D, Archimède H. Nutritional requirements of sheep, goats and cattle in warm climates: a meta-analysis. Animal. (2014) 8:143947. doi: $10.1017 / \mathrm{S} 1751731114001153$

16. Weiss WP. Symposium: prevailing concepts in energy utilization by ruminants. Predicting energy values of feeds. J Dairy Sci. (1993) 76:180211. doi: 10.3168/jds.S0022-0302(93)77512-8

17. NRC. Nutrient Requirements of Beef Cattle, 7 Edn. Washington, DC: National Academy Press (2000).

18. Chen XB, Gomes JM. Estimation of microbial protein supply to sheep and cattle based on urinary excretion of purine derivatives: an overview of the technical details. Occasional Publication of the International Feed Resources Unit. Rowett Research Institute. Bucksburn, Aberdeen (1992).

19. AOAC. Official Methods of Analysis, 15th Edn. Washington, DC: AOAC International (1990).

20. Van Soest PJ, Robertson JB, Lewis BA. Methods for dietary fiber, neutral detergent fiber, and non-starch polysaccharides in relation to animal nutrition. J Dairy Sci. (1991) 74:3583-97. doi: 10.3168/jds.S0022-0302(91)78551-2

21. Mertens DR, Allen M, Carmany J, Clegg J, Davidowicz A, Drouches M, et al. Gravimetric determination of amylase-treated neutral detergent fiber in feeds with refluxing in beakers or crucibles: collaborative study. J AOAC Int. (2002) 85:1217-40.

22. Licitra G, Hernandez TM, Van Soest PJ. Standardization of procedures for nitrogen fractionation of ruminant feeds. Anim Feed Sci Tech. (1996) 57:34758. doi: 10.1016/0377-8401(95)00837-3

23. Sniffen CJ, O'Connor JD, Van Soest PJ, Fox DG, Russell JB. A net carbohydrate and protein system for evaluating cattle diets: II. carbohydrate and protein availability. J Anim Sci. (1992) 70:3562-77. doi: 10.2527/1992.70113562x

24. ARC. The Nutrient Requirement of Ruminant Livestock. Slough: Commonwealth Agricultural Bureaux (1980).

25. Chizzotti ML, Tedeschi LO, Valadares Filho SC. A meta-analysis of energy and protein requirements for maintenance and growth of Nellore cattle. J Anim Sci. (2008) 86:1588-97. doi: 10.2527/jas.2007-0309

26. Ferrell CL, Jenkins TG. Body composition and energy utilization by steers of diverse genotypes fed a high-concentrate diet during the finishing period: II. Angus, Boran, Brahman, Hereford, and Tuli sires. J Anim Sci. (1998) 76:64757. doi: $10.2527 / 1998.762647 \mathrm{x}$
27. Wilkerson VA, Klopfenstein TJ, Britton RA, Stock RA, Miller PS Metabolizable protein and amino acid requirements of growing cattle. J Anim Sci. (1993) 71:2777-84. doi: 10.2527/1993.71102777x

28. Nsahlai IV, Goetsch AL, Luo J, Johnson ZB, Moore JE, Sahlu T, et al. Metabolizable energy requirements of lactating goats. Small Rumin Res. (2004) 53:253-73. doi: 10.1016/j.smallrumres.2004.04.007

29. Tedeschi LO, Fox DG, Guiroy PJ. A decision support system to improve individual cattle management. 1. A mechanistic, dynamic model for animal growth. Agric Syst. (2004) 79:171-204. doi: 10.1016/S0308-521X(03)00070-2

30. Teixeira IAMA, Fernandes MHMR, Filho JMP, Canesin RC, Gomes RA, Resende KT. Body composition, protein and energy efficiencies, and requirements for growth of $\mathrm{F} 1$ Boer $\mathrm{x}$ Saanen goat kids. J Anim Sci. (2017) 95:2121-32. doi: 10.2527/jas.2016.1252

31. Galvani DB, Pires CC, Kozloski GV, Wommer TP. Energy requirements of Texel crossbred lambs. J Anim Sci. (2008) 86:348090. doi: 10.2527/jas.2008-1097

32. Vermorel M, Bickel H. Utilization of feed energy by growing ruminants. Ann Zootech. (1980) 29:127-43.

33. Garrett WN. Factors influencing energetic efficiency of beef production. $J$ Anim Sci. (1980) 51:1434-40. doi: 10.2527/jas1981.5161434x

34. Graham RM. Variation in energy and nitrogen utilization by sheep between weaning and maturity. Austr J Agric Res. (1980) 31:335-45.

35. Tedeschi LO, Cannas A, Fox DG. A nutrition mathematical model to account for dietary supply and requirements of energy and other nutrients for domesticated small ruminants: the development and evaluation of the Small Ruminant Nutrition System. Small Rumin Res. (2010) 89:17484. doi: 10.1016/j.smallrumres.2009.12.041

36. Luo J, Goestch AL, Nsahlai IV, Sahlu T, Ferrell CL, Owens $\mathrm{FN}$, et al. Metabolizable protein requirements for maintenance and gain of growing goats. Small Rumin Res. (2004) 53:30926. doi: 10.1016/j.smallrumres.2004.04.003

37. CSIRO. Feeding Standards for Australian Livestock. Ruminants. Melbourne: CSIRO Publications (1990).

38. AFRC. Nutritive Requirements of Ruminant Animals: Protein (Report 9). Nutr Abstr Rev. (1992) 62:787-835.

39. AFRC. Energy and Protein Requirements of Ruminants. Wallingford: CAB International (1993).

40. Cantalapiedra-Hijar G, Ortigues-Marty I, Sepchat B, Agabriel J, Huneau JF Fouillet H. Diet-animal fractionation of nitrogen stable isotopes reflects the efficiency of nitrogen assimilation in ruminants. Br J Nutr. (2015) 113:115869. doi: 10.1017/S0007114514004449

41. Galvani DB, Pires CC, Kozloski GV, Sanchez LMB. Protein requirements of texel crossbred lambs. Small Rumin Res. (2009) 81:55-62. doi: 10.1016/j.smallrumres.2008. 11.003

Conflict of Interest: The authors declare that the research was conducted in the absence of any commercial or financial relationships that could be construed as a potential conflict of interest.

Copyright (C) 2021 Mendes, Souza, Herbster, Brito Neto, Silva, Rodrigues, Marcondes, Oliveira, Bezerra and Pereira. This is an open-access article distributed under the terms of the Creative Commons Attribution License (CC BY). The use, distribution or reproduction in other forums is permitted, provided the original author(s) and the copyright owner(s) are credited and that the original publication in this journal is cited, in accordance with accepted academic practice. No use, distribution or reproduction is permitted which does not comply with these terms. 